\author{
Stanisław Rychlicki*, Piotr Kosowski*, Joanna Wartak*, \\ Marek Solecki*
}

\title{
SOCIAL ACCEPTANCE FOR CO-EOR AND CCS \\ PROJECTS BASED ON SURVEY CONDUCTED IN SOUTHEASTERN POLAND**
}

\section{INTRODUCTION}

Economic development is inextricably linked to the usage of energy. Currently in Poland the main sources of energy are largely non-renewable. Energy from renewable sources now accounts for a small percentage of the overall resources. Increasing demand for energy makes it necessary to make investments aimed at finding new hydrocarbon reservoirs and increasing production from existing fields.

When a reservoir's natural energy is exhausted or is too small and primary recovery methods (a reservoir's natural energy is used) ceases to be profitable secondary and tertiary methods of oil production are used. Secondary methods use physical mechanisms of displacement - injecting water or gas into the reservoir, and the tertiary methods (EOR - Enhanced Oil Recovery) consist in supporting the production process by providing energy that replaces or assists primary and secondary mechanisms of repression [1-4]. EOR methods utilize operations based among others on the delivery of heat, changing the properties of oil and chemical reactions occurring between injected fluids and oil [5]. The use of tertiary methods of extraction at the initial stage of exploitation makes it possible to increase the efficiency of their production, thereby to lower operating costs. One of most popular EOR methods is injecting $\mathrm{CO}_{2}$ into the reservoir [6]. Intensification of oil recovery using carbon dioxide is most effective when the composition of oil and reservoir conditions allow for mixing of the injected gas with oil. In the case of a significant density and too low oil pressure injected gas is used only as a displacing medium, since it is not mixed with oil.

Particular attention is aroused by projects that combine the technologies of production intensification using carbon dioxide $\left(\mathrm{CO}_{2}\right.$-EOR) and carbon capture and storage (CCS). $\mathrm{CCS}$ involves the capture of carbon dioxide emitted by industrial installations and its subsequent

\footnotetext{
* AGH University of Science and Technology, Faculty of Drilling, Oil and Gas, Krakow, Poland

** The research leading to these results has received funding from the Polish-Norwegian Research Programme operated by the National Centre for Research and Development under the Norwegian Financial Mechanism 2009-2014 in the frame of Project Contract No. Pol-Nor/235294/99/2014
} 
injection into the pores of the deep geological rock structures. This method allows for the neutralization of large amounts of $\mathrm{CO}_{2}$ from large industrial sources of emissions [7]. Depleted and partially depleted oil and gas reservoir are well recognized and therefore provide an excellent reservoirs for the storage of carbon dioxide [8]. A combination of technologies of $\mathrm{CO}_{2}$-EOR and CCS enables enhancement of oil recovery as well as a reduction of carbon dioxide emissions to the atmosphere while minimizing the cost of $\mathrm{CO}_{2}$ capture and storage.

The successful implementation of new technology depends on multiple factors such as technological developments, economic profits and societal acceptance. Social attitude towards the investment, especially the investment of oil is very important. Lack of social acceptance could result in the inhibition of the development of investment and even decide on the total resignation of it. Public concern regarding new investments are often associated with a lack of basic knowledge about their functioning and related possible impact on human health and the environment. Therefore it is extremely important to know the public sentiment associated with a particular type of investment, and to form it through appropriate educational and informational policies.

Due to the possibility of using modern technologies ( $\mathrm{CO}_{2}$-EOR and CCS), a survey has been done among residents of areas taken into account in the project of underground gas storage.

\section{SAMPLE DESCRIPTION}

The study has been done on a sample of 90 people living in the region of Krosno, Jedlicze and Rymanów (SE Poland). In this area oil fields have been exploited since the XIX century, and a significant part of the local population is or was employed in the petroleum industry. In this region there are reservoirs with very good parameters of oil and gas and the modern petroleum industry started there in the mid- $19^{\text {th }}$ century.

In terms of age, the sample was dominated by people between 41 and 50 years old (29\%) and between 15 and 20 years old (19\%). In terms of education most respondents marked higher education (57\%), followed by secondary education (33\%) and basic education $(6 \%)$. $4 \%$ of respondents did not answer a question about education. Histograms presenting the structure of the sample are in Figures 1-3.

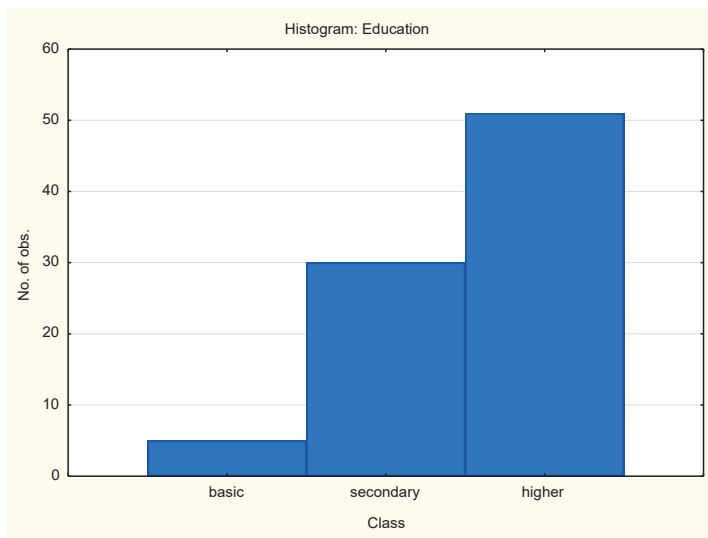

Fig. 1. Histogram showing the education structure of respondents 


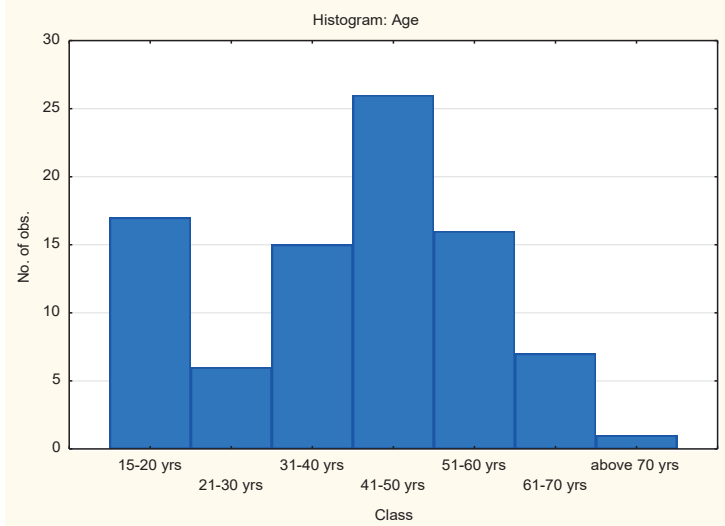

Fig. 2. Histogram showing the age structure of respondents

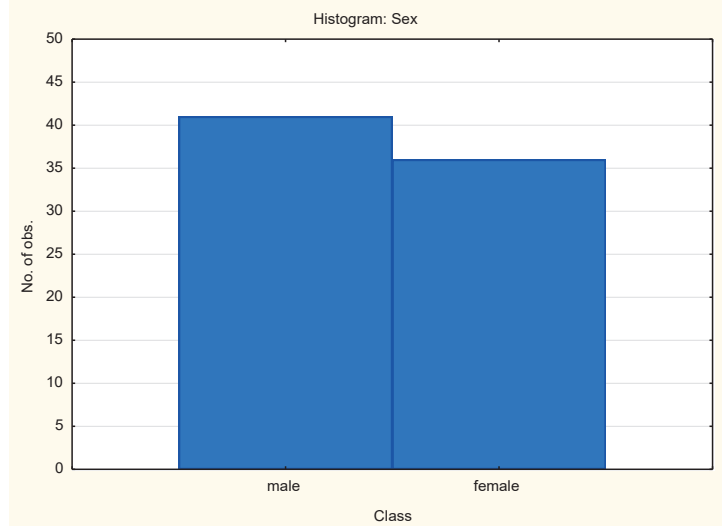

Fig. 3. Histogram showing the gender structure of respondents

Surveys were carried out within the MUSE project to determine the impact of oil on the surrounding environment and the level of knowledge, perception and acceptance of CCS and $\mathrm{CO}_{2}$-EOR methods.

\section{SURVEY}

The survey contained 60 questions divided into three thematic groups.

1. The general state of knowledge of oil exploitation and perception of oil industry (questions 1-4), e.g. sources covering demand for oil in Poland, development of petroleum industry etc.

2. The impact of oil exploitation on the environment and people's health.

- Questions from 5 to 51 concerned the state of environment (in respondent's living place) and impact of petroleum industry on it, perceptible negative effects of pollution and its causes. Questions from 5 to 11 concerned the general statement 
of environment, while questions from 12 to 51 focused on environmental factors, as: air (12-18), water (19-29), soil (30-34), flora (35-38), fauna (39-42), landscape (43-46).

- In the questions 47 and 48 respondents had to indicate the most transformed/degraded element of environment. The impact of oil exploitation to health of people has been included in questions 49 to 51 .

3. Knowledge and assessment of CCS and $\mathrm{CO}_{2}$-EOR technologies to enhance oil recovery (52-60).

- This group concentrated on the opinion of respondents about the development of new oilfields, increasing of recovery from existing reservoirs, reactivation of old reservoirs. Respondents had to refer to use modern technologies (CCS and $\mathrm{CO}_{2}$-EOR) in investments related to petroleum industry. This part also concentrated on benefits and risks connected with these technologies.

In this paper authors focused on modern technologies (CCS and $\mathrm{CO}_{2}$-EOR) in investments related to petroleum industry. The other results of this survey will be presented in next papers.

Most of the questions are closed single- or multiple-choice. The data obtained from the survey were introduced into the STATISTICA. The numeration of questions was taken from the survey.

\section{SURVEY'S RESULTS}

The first question taken into account in this paper (Fig. 4) concerned the development of oil industry in Poland. On this question, 65\% of respondents replied "yes". The opposite opinion is shared by only $10 \%$ of respondents, while $25 \%$ have no opinion on the subject. Next two questions (Figs 5 and 6) concerned the use of the newest technologies to increase oil recovery from existing and reactivating Polish oilfields. On this questions can be seen analogous answers to the previous one. For the application of new extraction technology is $63 \%$ of the respondents, the opposite is only $5 \%$, while $31 \%$ have no opinion on the subject.

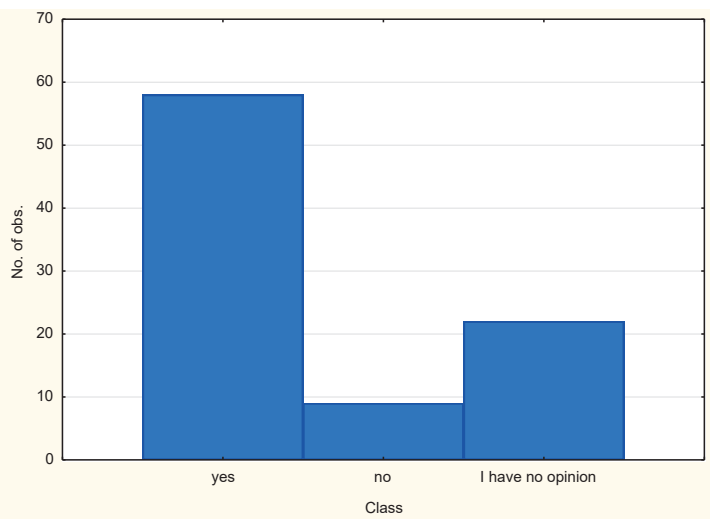

Fig. 4. Do you think that there is need to develop new oilfields in Poland? 


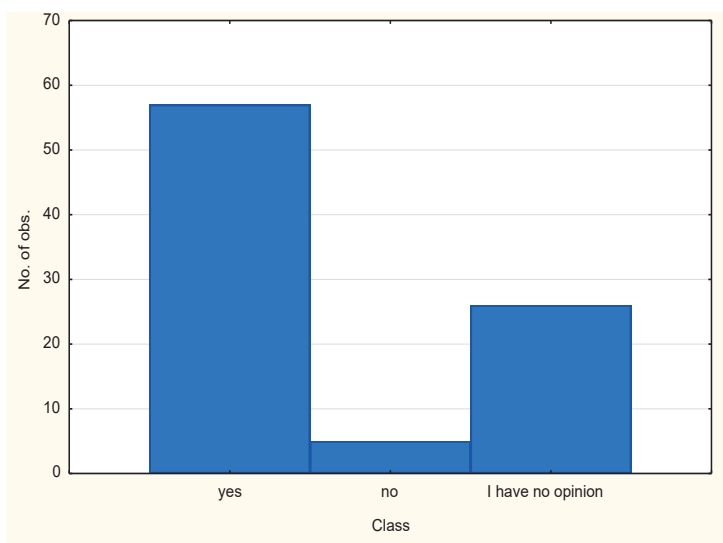

Fig. 5. Do you think that the efforts should be made to increase oil recovery from existing fields in Poland by using the new technologies?

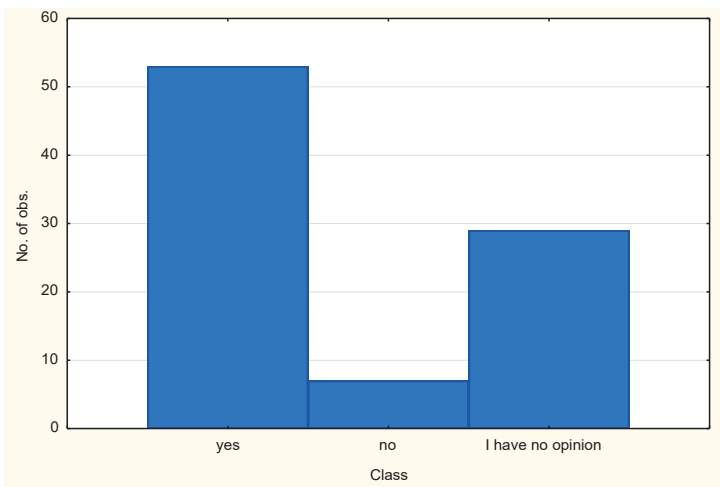

Fig. 6. Do you think that efforts should be made to reactivate the old reservoirs (where unexcavated oil resources remain) using modern technologies of exploitation?

Again, it can be observed as in the previous two questions, the analogy of answers. $59 \%$ of respondents think that the old reservoirs should be reactivated, $8 \%$ are opposed to this action, while $33 \%$ have no opinion on the subject.

After analyzing the distribution of answers to previous three questions it can be observed that the majority of people are aware of the need to apply modern technology to extract oil (approx. 60\%), while also large group (approx. 30\% of respondents) does not have opinion on these technologies. It shows us that there is a request on the proper education related to the using of modern technologies.

Next few questions (Fig. 7-12) concern the opinion on the new technologies for oil recovery. It can be seen, that the majority of respondents (45-69\%) have not any opinion about new technologies of oil recovery and have not heard about it before. It can be also observed that the second biggest group (21-45\%) have positive opinion about introducing this methods. 


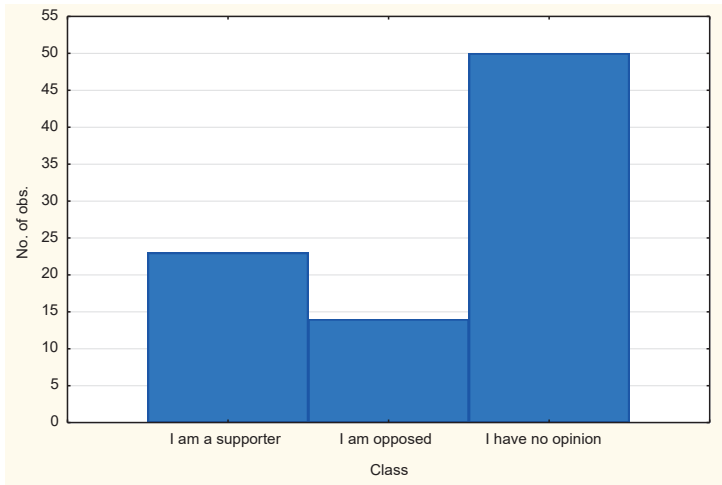

Fig. 7. What is your opinion regarding to the use of carbon dioxide in order to increase oil recovery in the active oil fields?

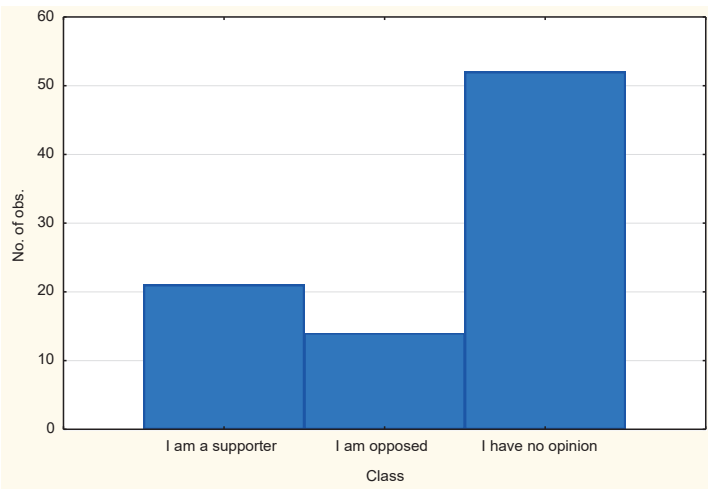

Fig. 8. What is your opinion regarding to the use of carbon dioxide in order to increase oil recovery in the old oil fields?

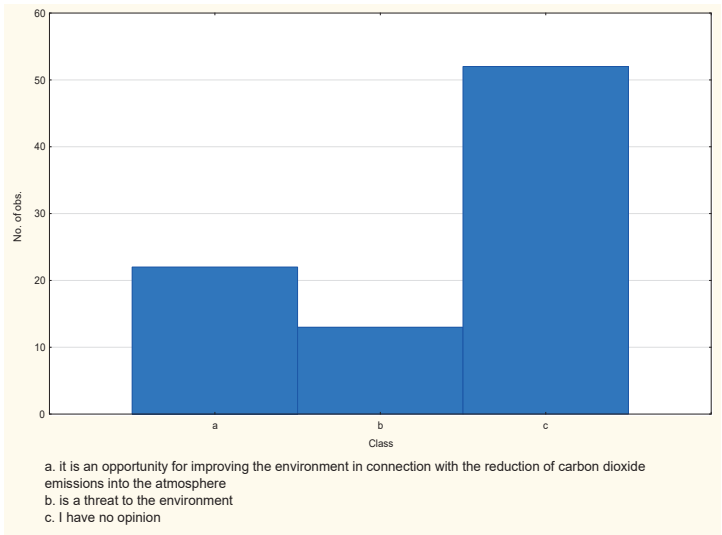

Fig. 9. Do you think that the application of modern exploitation methods using carbon dioxide in order to increase the production of oil? 


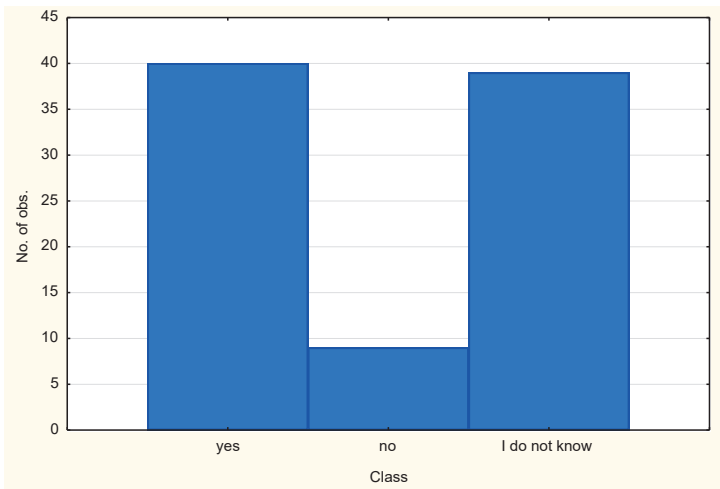

Fig. 10. Would the inhabitants of your area be interested in working for restored old oil fields using new technology and carbon dioxide to increase oil recovery?

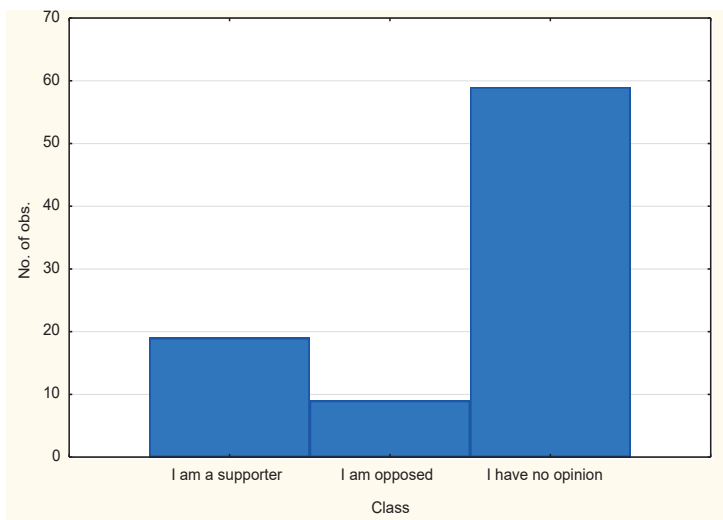

Fig. 11. What is your opinion with regard to carbon dioxide injection into the ground in order to remove it from the atmosphere?

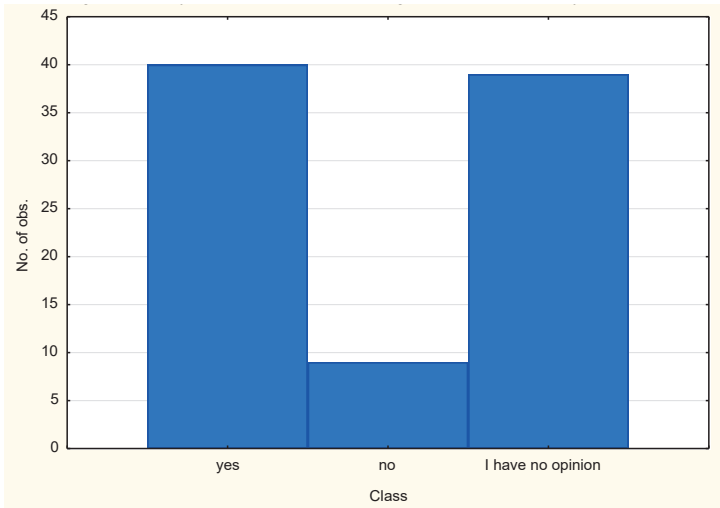

Fig. 12. Do you think that modern technologies used in the oil industry are safe? 
However, due to the large number of people expressed no opinion on this issue, it can be assumed that respondents who declare themselves as opponents of $\mathrm{CO}_{2}$-EOR method, defined their position on the basis of they had heard (not necessarily true), their concerns related to the use new technologies or incomplete knowledge of the methodology discussed.

The next diagrams show the relationship between environmental issues depending on place of reside/stay (in terms of the activities of the oil industry, Fig. 13-20).

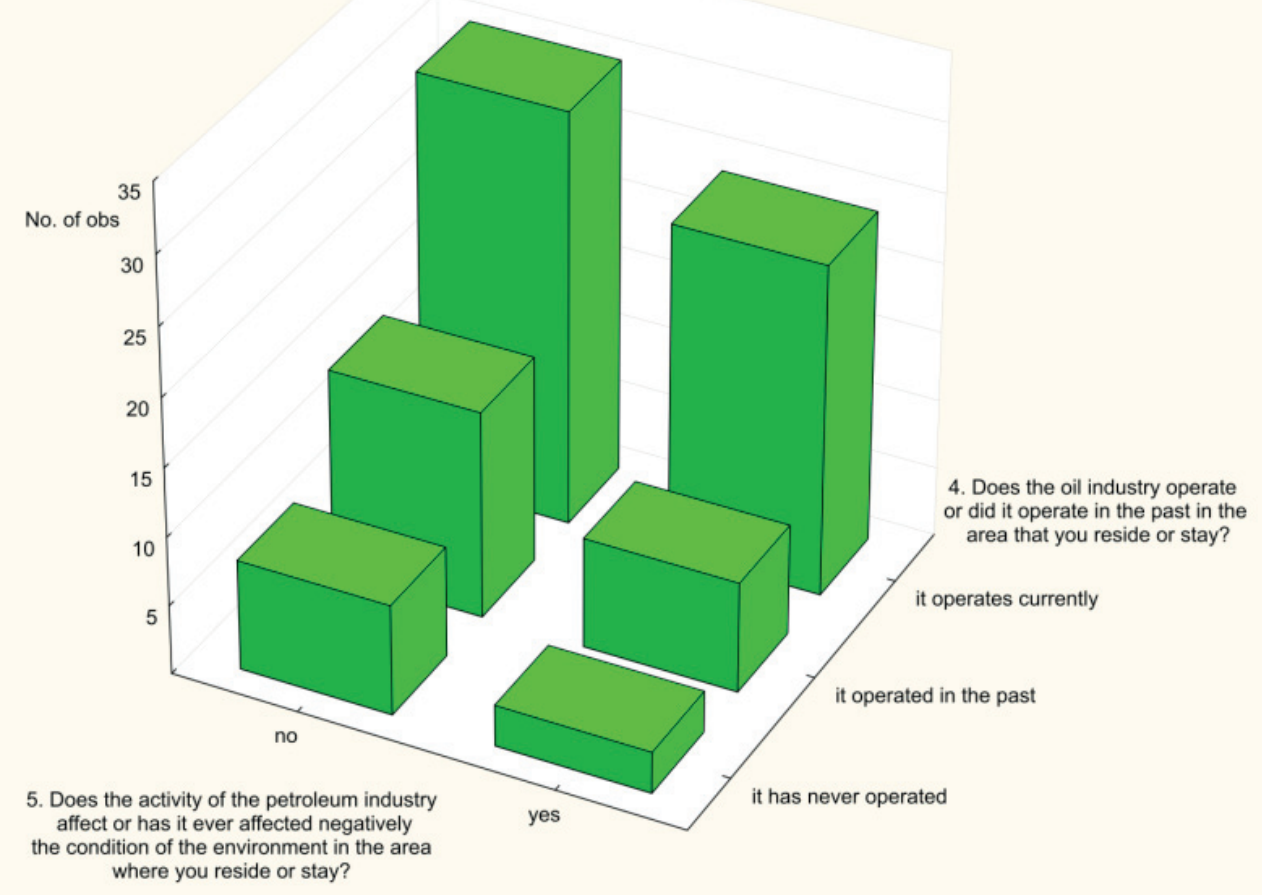

Fig. 13. Relationship of the environment condition from the activities of the oil industry

According to almost $28 \%$ of respondents from the places where the oil industry is currently operating, negative impact on the environment can be seen. The opposite opinion is shared by $34 \%$ of respondents in those places. $9 \%$ of respondents from the places where the oil industry operated in the past, feel or felt the negative impact of industry on the environment, while $17 \%$ have not felt it. $3 \%$ of the respondents, from places where oil industry never operated, feels or felt a negative impact on the environment (this can be caused, for example by transport of petroleum substances), and 9\% - did not see such effects. Such results show, that there should be taken actions to reduce the negative impact of the oil industry on the environment. Nevertheless, majority of respondents does not see negative effects causing by petroleum industry. 


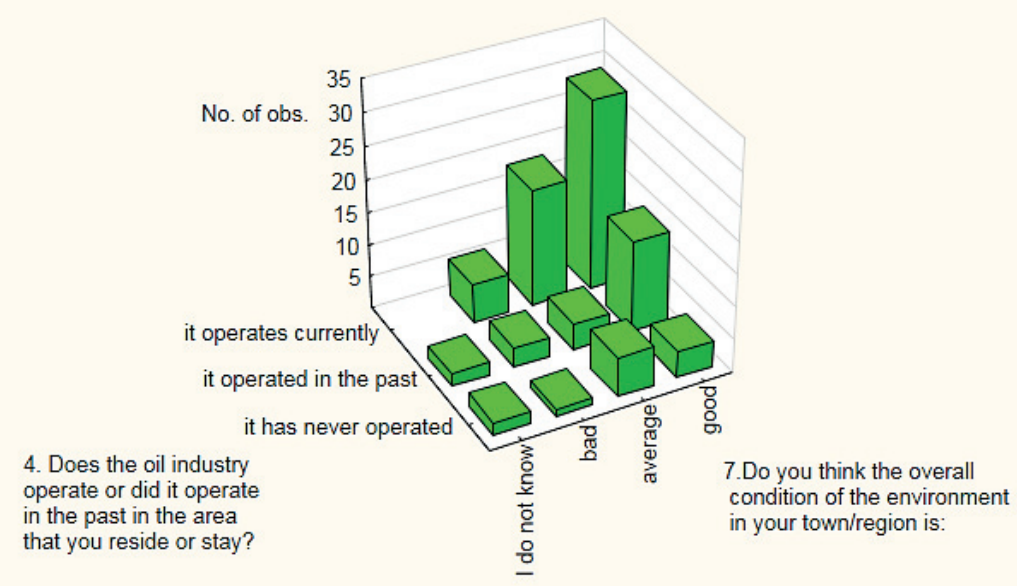

Fig. 14. Dependence of the overall condition of the environment in the of respondents places of living from the activities of the oil industry

Here can be seen some differences between this and previous diagram. Over 32\% people from towns where the oil industry operates currently, believes the environment condition in their area of living is good. The same answer give $16 \%$ of respondents who answered that the oil industry operated in the past in their area of living. As the average condition of the environment reported $20 \%$ of respondents from towns where the oil industry operates currently. Poor condition indicated only $7 \%$ of respondents. The small percentage of respondents who said they chose the answer "bad" and the fact that in the previous question, as many as $28 \%$ respondents of the regions, where the oil industry operates currently claims that it has a negative impact on the environment can be concluded that the impact must not be greatly felt by the respondents. Selection by $28 \%$ of respondents answered in question 5 ("Does the activity of the petroleum industry affect or has it ever affected negatively the condition of the environment in the area where you reside or stay?") can be caused due to its too general statement. It can be assumed that the respondents answering this question were guided not by own observations, but their judgment influenced by the media publicized oil rigs damages or oil spills in the oceans.

$43 \%$ of respondents from towns where the oil industry operates currently, believes that it should be developed in Poland ( $8 \%$ say that yes, but not in their area). The same point of view present $20 \%$ of the inhabitants of the places, where the oil industry operated in the past. This shows a trend depending on the development of the oil industry of the origin of the respondent. As many as $73 \%$ of the inhabitants of the places, where oil industry currently operates or operated in the past, would like to develop it. Respondents see that development of Polish oil industry is a big chance to increase our energetic independence and boost economy. In Carpathian region, in many places, petroleum industry is the only workplace for people. The development of petroleum industry, especially in their region, may be an impulse to increase the activity of the local community. 


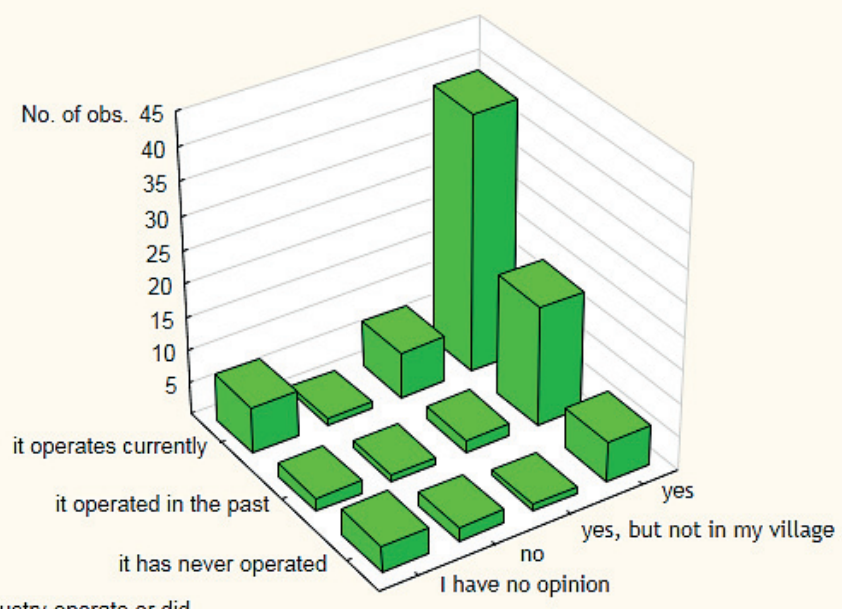

4. Does the oil industry operate or did it operate in the past in the area that you reside or stay?

\section{Do you think that the oil industry should develop in Poland?}

Fig. 15. Dependence of residence (in terms of the activities of the oil industry) to the issue of further development of the oil industry in the country

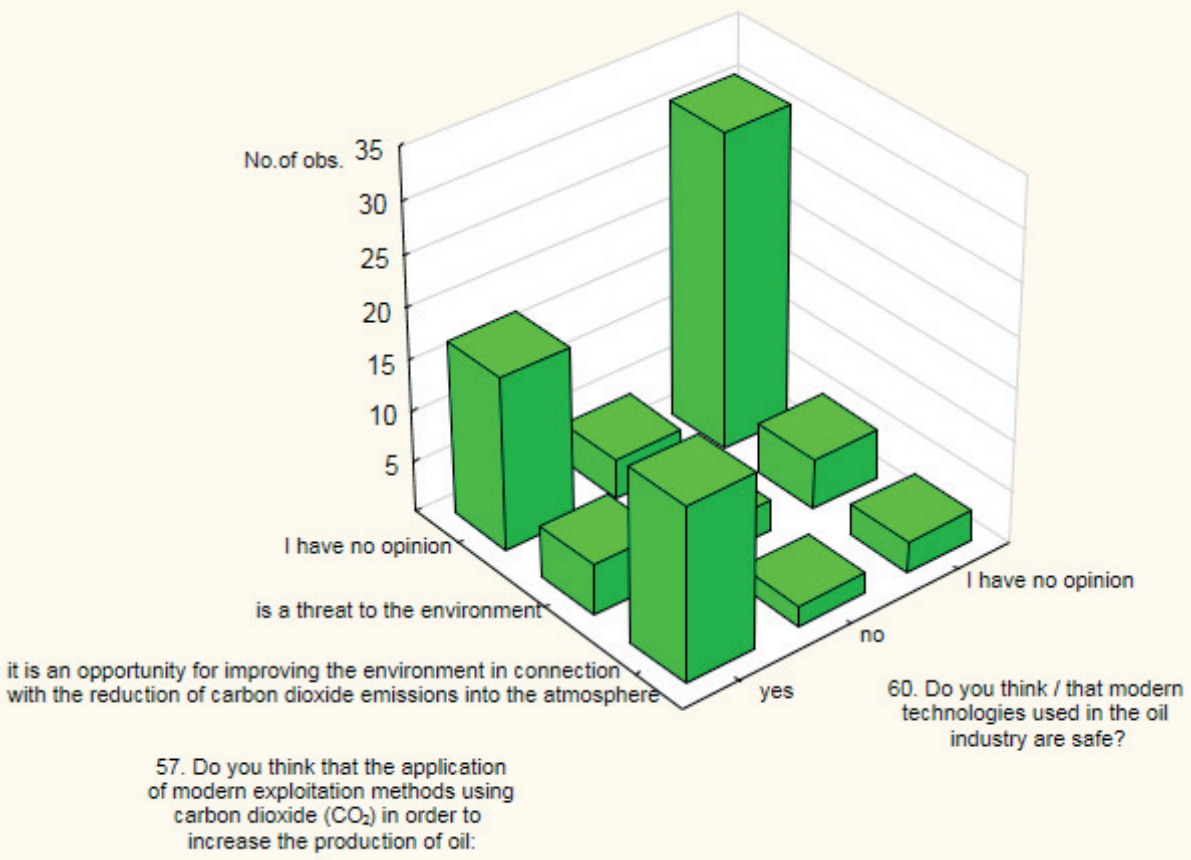

Fig. 16. Summary of questions concerning opinions on the use of $\mathrm{CO}_{2}$-EOR methods to increase oil production and safety assessment of modern technologies used in the oil industry 


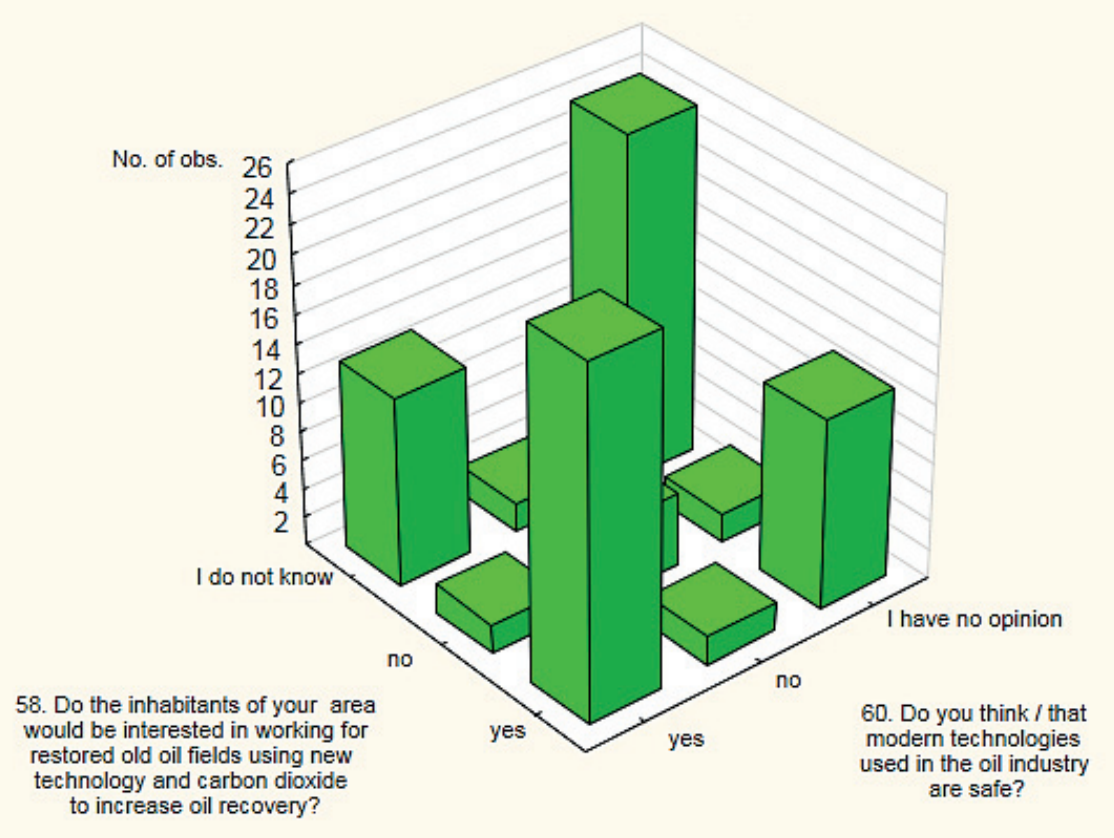

Fig. 17. Juxtaposition of employment opportunities for restored to service old oil fields and the safety of modern extraction technology

At first glance, it appears that a large proportion of respondents (almost 36\%) have no opinion on both questions. This presents a need for increased public education so that it can establish knowledge and rationally thinking about modern technologies. It is encouraging that almost $20 \%$ of respondents who see a chance to improve the environment in connection with the use of $\mathrm{CO}_{2}$ into operation, believes that modern technologies are safe. The same number of respondents who have no opinion on the use of $\mathrm{CO}_{2}$ technology, believes that it is safe. This gives a total of almost $45 \%$ of respondents who consider this technology to be safe and as many who do not have an opinion on safety. This only confirms the thesis that society should be educated and that people are not afraid of new technologies.

Here, the voices of respondents split up equally. Many people do not have opinion on both subjects (a total of almost 28\%) and also the same amount would like to work and are not afraid of modern technology. After looking at the diagram it can be also seen a lack of knowledge on topics related to modern technologies and advantage of people interested in this subject and not afraid of novelty over those who have doubts. Nonetheless, residents can see the benefits of new oil investments, majority believes that modern technologies are an economic development of the region. People would like to work in petroleum industry, because it has been working here since XIX century, so they are familiar with it. Also, increase of unemployment in SE Poland motivates people to work in new-opened places.

It can be seen that most of respondents would like both developing the oil industry in Poland and think that modern technologies used in the oil industry are safe (37\%). Up to $27 \%$ people wants to develop the oil industry, but have no opinion about new technologies. It gives 
almost $65 \%$ of respondents who would like to develop oil industry and are not afraid (or have no opinion) about new technologies. Only 5\% of respondents are afraid of new technologies, but they want to develop oil industry in Poland. Over 10\% of respondents do not have opinion on both topics. The positive attitude of the respondents with regard to oil investments using modern technologies is particularly important because the field of research is potential area for new investments.

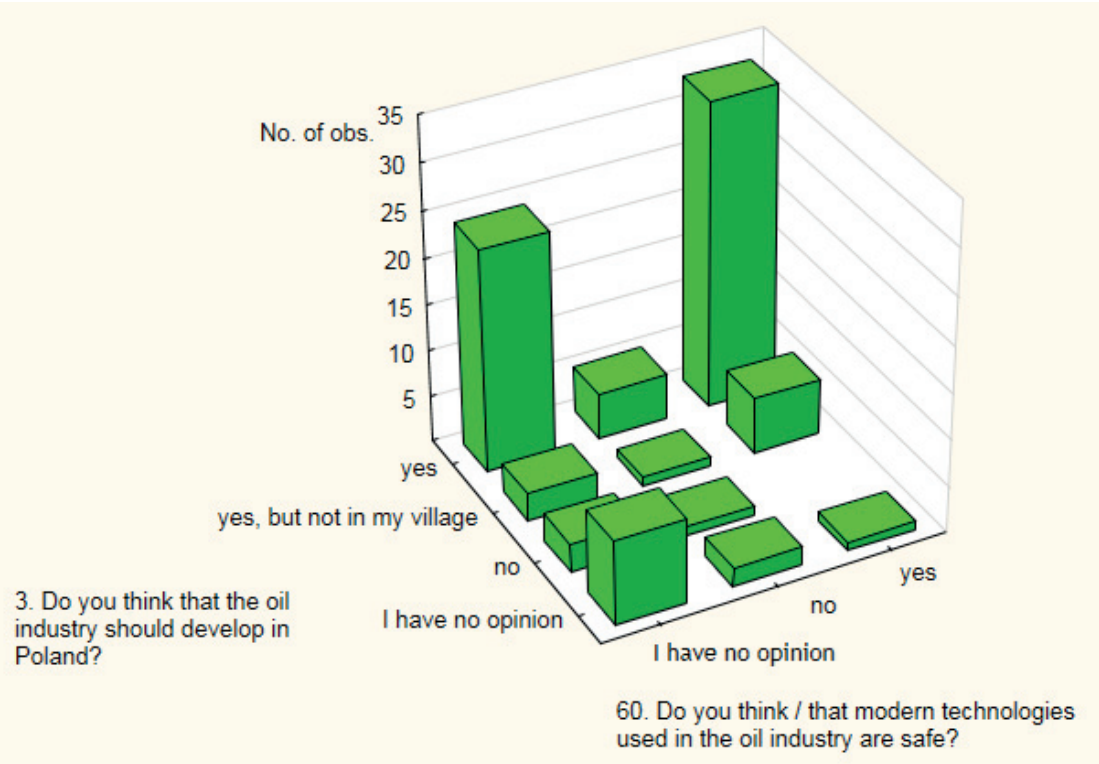

Fig. 18. Comparison the topic of developing the oil industry in Poland with the safety of modern technologies used in it

At first, it can be seen that most of people do not have any opinion about using $\mathrm{CO}_{2}$ to increasing the production of oil (59\%). But, there is also seen, that $82 \%$ of respondents answered "good" or "average" in question about the condition of environment. Next observation is that $24 \%$ of respondents who answered that modern technologies using $\mathrm{CO}_{2}$ can be an opportunity for improving the environment, observed environment condition in their place of reside as "good" or "average". No one of them answered "bad" for the environment condition. Respondents see that modern methods using carbon dioxide to enhance oil recovery is a chance for improving the environment.

It can be seen that most of people do not have opinion about modern technologies. $69 \%$ of respondents do not have any opinion about $\mathrm{CO}_{2}$ injection into the ground. The answers are very similar to the previous juxtaposition. It can be seen that only $9 \%$ of respondents are against $\mathrm{CO}_{2}$ injection to the ground. Respondents understand that modern methods using carbon dioxide to enhance oil recovery is a chance for improving the environment due to the reduction of carbon dioxide emissions into the atmosphere. 


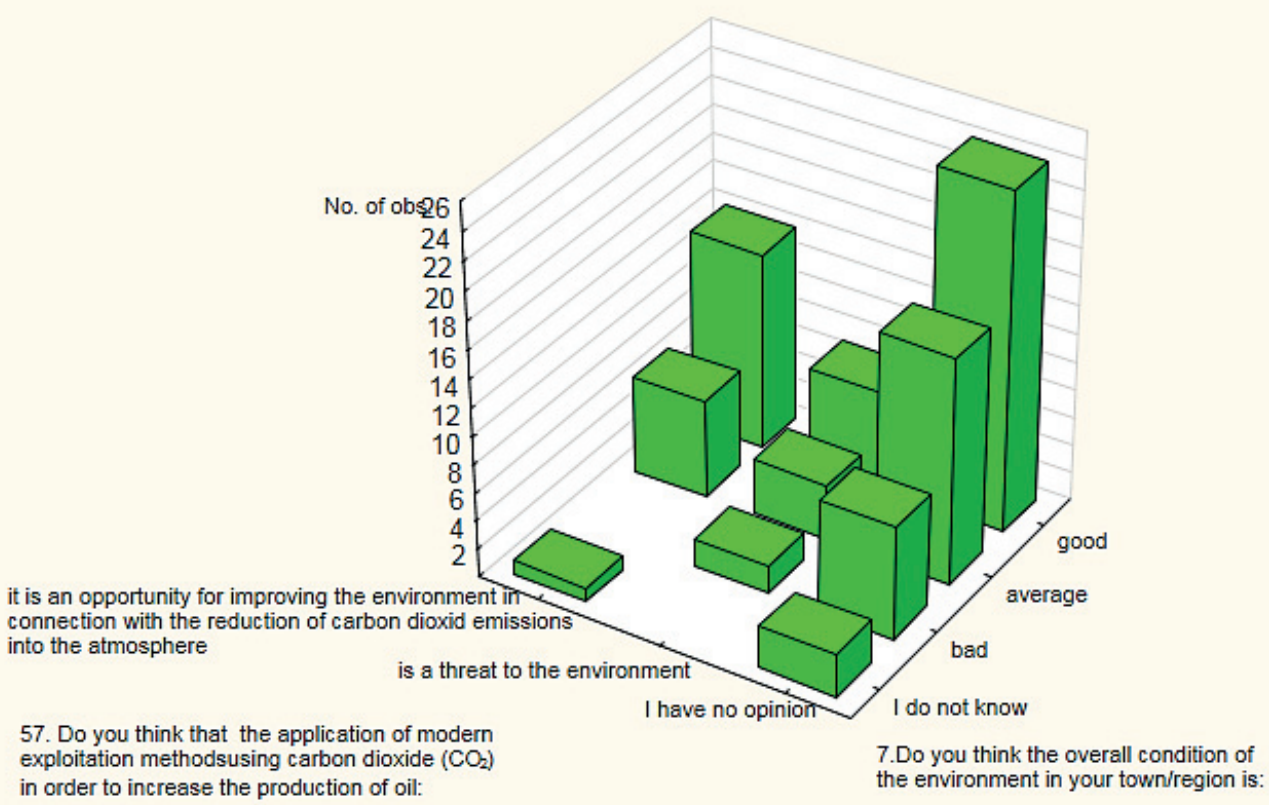

Fig. 19. Juxtaposition of question about the condition of environment in region where respondent live, with question about using modern technologies in order to production more oil

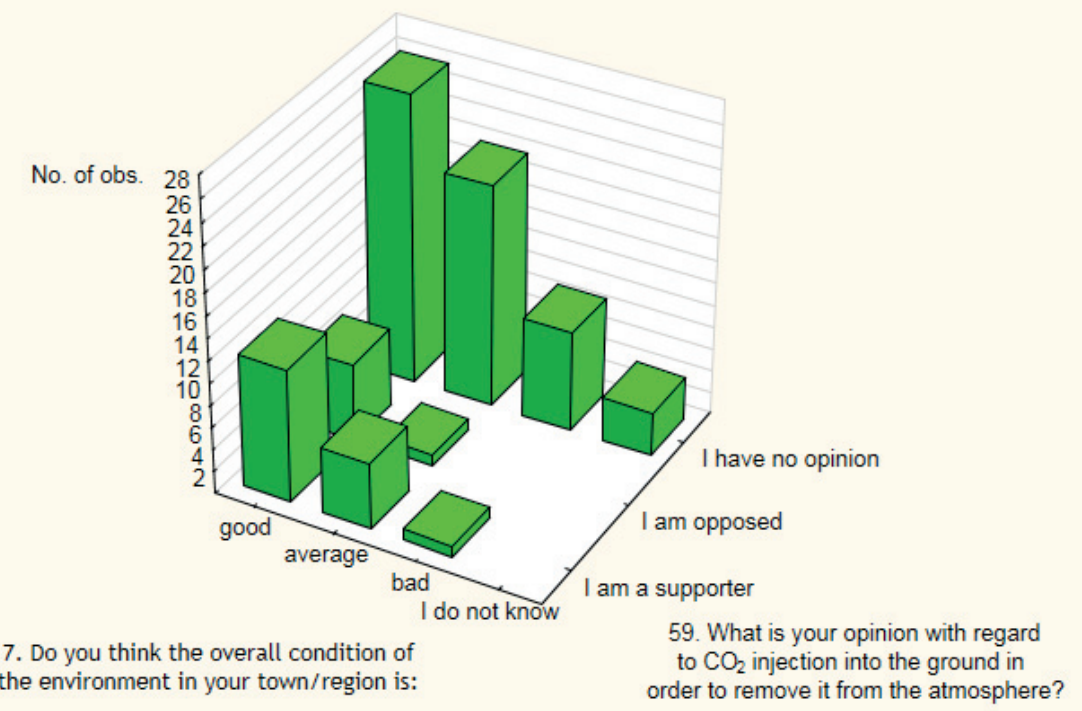

Fig. 20. Comparison the condition of environment with using $\mathrm{CO}_{2}$ injection into the ground in order to remove it from the atmosphere 


\section{SUMMARY}

The research shows that the public is aware of the need of development of the oil industry in Poland. Respondents recognize the need to use modern technologies such as $\mathrm{CO}_{2}$-EOR and CCS to fulfill this task. The survey was carried out in areas that have for a long time been in contact with the oil industry. Respondents live in the places, where petroleum industry is an element inseparably connected with their daily life and often is the main source of living. The development of new oilfields in Poland, especially in this region, is seen by the respondents as a chance for them. People base their opinions on real experiences, and they do not yield to the pressure (or they do in lesser extent) of media. Residents can see more benefits than risks of new oil investments, majority believes that modern technologies are safe and are an opportunity for environmental improvement and economic development of the region. Respondents understand that modern methods using carbon dioxide to enhance oil recovery are a chance for improving the environment due to the reduction of carbon dioxide emissions into the atmosphere. Most of the respondents are willing to work for the restored petroleum industry. The positive attitude of the respondents with regard to oil investments using modern technologies is particularly important because the field of research is a potential area for new investments. According to Figures 4-6 and 8, it can be seen that people perceive the chance connected with $\mathrm{CO}_{2}$-EOR and CCS methods to decrease the pollution of atmosphere by storing $\mathrm{CO}_{2}$ in reservoirs, what also lets us to increase the recovery of oil. Lack of sufficient information about modern technologies is a main reason, why people do not have an opinion about them. Success of renewable sources of energy was caused by wide range of mainly positive information. In the case of $\mathrm{CO}_{2}$-EOR and CCS technologies, only people connected with petroleum industry have enough knowledge about it. Thus, responsible politics and reliable education are necessary to familiarize people with $\mathrm{CO}_{2}$-EOR and CCS. Without taking this type of action, the number of opponents, which is the lowest at all of analyzed figures, can change in a negative way.

A significant number of respondents show limited awareness (or lack of it) regarding these technologies. In order to obtain public acceptance for future projects using the technology of $\mathrm{CO}_{2}$-EOR and CCS educational and informative actions should be taken. Beliefs formed on the basis of the limited information do not allow for a realistic assessment of the risks and benefits of implementing new technology. It is necessary not only to familiarize the public with the operation of the technology but also to present to the society reliable information on good identification of the geological structure and the assessment of risk associated with $\mathrm{CO}_{2}$ storage. Public acceptance largely depends on the level of knowledge regarding the technology. Some issues relating to CCS and EOR methods are, however, incomprehensible to the majority of the population. Because of that, public opinion is often formulated on the basis of technology assessment made by experts from the industry as well as government representatives and NGOs. Thus the information provided by these groups should come from a careful analysis of the benefits and risks of the implementation of these technologies. It is particularly important that the public can be certain that law regulations on $\mathrm{CCS}$ and $\mathrm{CO}_{2}$-EOR allow the use of these technologies only when they are implemented in a given region in a way that is safe both for people and the environment [9]. The information on the natural analogues could decrease the risk perception and increase public acceptance of $\mathrm{CO}_{2}$ geological storage [10]. 
Accordingly, one of the main directions of work undertaken prior to the implementation of industrial installations using technologies of $\mathrm{CO}_{2}$-EOR and CCS should be gaining the acceptance of the local community.

\section{REFERENCES}

[1] Trujillo M., Mercado G., Maya G., Castro R., Soto C., Perez H., Gomez V.: Sandoval J.: Selection Methodology for Screening Evaluation of Enhanced - Oil-Recovery Methods. SPE 139222, 2010.

[2] Stopa J., Wojnarowski P., Kosowski P.: Ekonomika sekwestracji geologicznej $\mathrm{CO}_{2}$ w złożach ropy naftowej. Polityka Energetyczna, vol. 9, 2006, pp. 319-328.

[3] Wojnarowski P., Stopa J., Janiga D., Kosowski P.: Możliwości zwiększenia wydobycia ropy naftowej $w$ Polsce z zastosowaniem zaawansowanych technologii. Polityka Energetyczna, vol. 18, no. 4, 2015, pp. 19-28.

[4] Wojnarowski P.: Potential for increasing oil recovery from Polish oil-fields by applying EOR methods. Gospodarka Surowcami Mineralnymi, vol. 28, no. 4, 2012, pp. 47-58.

[5] Rychlicki S., Stopa J., Uliasz-Misiak B., Zawisza L.: Kryteria typowania złóż do zastosowania zaawansowanej metody wydobycia ropy naftowej poprzez zatłaczanie $\mathrm{CO}_{2}$. Gospodarka Surowcami Mineralnymi, vol. 27, no. 3, 2011, pp. 125-139.

[6] Stopa J., Wojnarowski P., Kosowski P., Pyrzak P.: Uwarunkowania techniczne i ekonomiczne sekwestracji $\mathrm{CO}_{2}$ w złożu ropy naftowej. Wiertnictwo, Nafta, Gaz, vol. 28, no. 3, 2011, pp. 533-541.

[7] Dubiński J., Wachowicz J., Koteras A.: Podziemne składowanie dwutlenku węla możliwości wykorzystania technologii CCS w polskich uwarunkowaniach. Górnictwo i Geologia, vol. 1, no. 5, 2010, pp. 5-19.

[8] Rychlicki S. (ed.): Możliwości zwiększenia efektywności wydobycia ropy naftowej ze złóż karpackich. Wydawnictwa AGH, Kraków 2010.

[9] Huijts N.M.A., Midden C.J.H. Meijnders A.L.: Social acceptance of carbon dioxide storage. Energy Policy, vol. 35, 2007, pp. 2780-2789.

[10] Tokushige K., Akimoto K., Tomoda T.: Public perceptions on the acceptance of geological storage of carbon dioxide and information influencing the acceptance. International Journal of Greenhouse Gas Control, vol. 1, 2007, pp. 101-112. 